\title{
Production of Selenomethionine-Enriched Bifidobacterium bifidum BGN4 via Sodium Selenite Biocatalysis
}

\author{
Weihong Jin ${ }^{1}$, Cheolho Yoon ${ }^{2}$, Tony V. Johnston ${ }^{3}{ }^{(0)}$, Seockmo Ku ${ }^{3, *}$ and Geun Eog Ji ${ }^{1,4, *}$ \\ 1 Department of Food and Nutrition, Research Institute of Human Ecology, Seoul National University, \\ Seoul 08826, Korea; kimweihong@hanmail.net \\ 2 Korea Basic Science Institute, 145 Anamro, Sungbuk-Gu, Seoul 02841, Korea; chyoon@kbsi.re.kr \\ 3 Fermentation Science Program, School of Agriculture, College of Basic and Applied Sciences, \\ Middle Tennessee State University, Murfreesboro, TN 37132, USA; tony.johnston@mtsu.edu \\ 4 Research Center, BIFIDO Co. Ltd., Hongcheon 25117, Korea \\ * Correspondence: Seockmo.Ku@mtsu.edu (S.K.); geji@snu.ac.kr (G.E.J.); \\ Tel.: +1-615-904-8290 (S.K.); +82-2-880-6282 (G.E.J.)
}

Academic Editor: Jose M. Palomo

Received: 21 September 2018; Accepted: 1 November 2018; Published: 2 November 2018

\begin{abstract}
Selenium is a trace element essential for human health that has received considerable attention due to its nutritional value. Selenium's bioactivity and toxicity are closely related to its chemical form, and several studies have suggested that the organic form of selenium (i.e., selenomethionine) is more bioavailable and less toxic than its inorganic form (i.e., sodium selenite). Probiotics, especially Bifidobacteriium and Lactobacillus spp., have received increasing attention in recent years, due to their intestinal microbial balancing effects and nutraceutical benefits. Recently, the bioconversion (a.k.a biotransformation) of various bioactive molecules (e.g., minerals, primary and secondary metabolites) using probiotics has been investigated to improve substrate biofunctional properties. However, there have been few reports of inorganic selenium conversion into its organic form using Bifidobacterium and Lactobacillus spp. Here we report that the biosynthesis of organic selenium was accomplished using the whole cell bioconversion of sodium selenite under controlled Bifidobacterium bifidum BGN4 culture conditions. The total amount of organic and inorganic selenium was quantified using an inductively coupled plasma-atomic emission spectrometer (ICP-AES). The selenium species were separated via anion-exchange chromatography and analyzed with inductively coupled plasma-mass spectrometry (ICP-MS). Our findings indicated that the maximum level of organic selenium was $207.5 \mu \mathrm{g} / \mathrm{g}$ in selenium-enriched B. bifidum BGN4. Selenomethionine was the main organic selenium in selenium-enriched B. bifidum BGN4 (169.6 $\mu \mathrm{g} / \mathrm{g})$. Considering that B. bifidum BGN4 is a commercial probiotic strain used in the functional food industry with clinically proven beneficial effects, selenium-enriched B. bifidum BGN4 has the potential to provide dual healthy functions as a daily supplement of selenium and regulator of intestinal bacteria. This is the first report on the production of organic selenium using B. bifidum spp.
\end{abstract}

Keywords: Bifidobacterium; functional foods; food additives; feed additives; probiotics; organic selenium; inorganic selenium; selenomethionine

\section{Introduction}

Selenium is a micronutrient essential to the maintenance of human health that plays an important role in human diseases, including cancer and cardiovascular diseases [1-3]. Selenium deficiency can cause Keshan disease and Kashin-Beck disease, both of which have high fatality rates [4,5]. Wei et al. [6] 
demonstrated that dietary selenium intake was useful for the suppression of Type 2 diabetes, both for onset and development. The US recommended daily allowance (RDA) of selenium is $55 \mu \mathrm{g}$ $(0.7 \mu \mathrm{mol}) /$ day [7]. According to the European Food Safety Authority (EFSA) [8], sodium selenite is the most common inorganic form of elemental selenium for human and animal use. However, selenium's bioactivity and toxicity are closely related to the form in which it exists, and several studies have suggested that the organic form of selenium is more bioavailable and less toxic than its inorganic form $[9,10]$.

According to a recent market research report [11], the U.S. probiotics market can be divided into three categories: (i) probiotic food and beverages, (ii) probiotic dietary supplements, and (iii) animal feed probiotics. Among them, the food and beverage sector demonstrated the largest growth in 2015 and accounted for more than 85\% (2.5 billion USD) of the total U.S. probiotic microorganism market sales. The remaining $10 \%$ and $5 \%$ of the market was dominated by dietary supplements and animal feed additives, respectively. Another industry report forecasts the global probiotics market will grow at a compound annual growth rate (CAGR) of 7.01\% from 2017-2021 [12]. Therefore, the major players in the food and nutraceutical industries are investing in research and business development (R\&BD) to diversify their product categories, gain competitive advantage, and develop differentiated probiotic bacteria to meet consumers' desires [13]. Among the various probiotic species, Bifidobacteriium and Lactobacillus spp. are commonly found in the naturally-occurring microbiota of healthy breast-fed infants' intestinal tracks. Bifidobacteriium and Lactobacillus have received increased attention in recent years as probiotics, due to their intestinal microbial balancing effects and medical benefits, including anti-inflammatory effects, alleviation of lactose intolerance, relief of constipation, anticholesterolaemic effects, anticancer activity, and tolerogenic immune responses to their hosts (human and animals) [13-16].

According to recent studies, some yeast strains (Saccharomyces cerevisiae and S. bayanus) [17,18] and mushrooms (Lentinus edodes) [19] have demonstrated the ability to take up inorganic selenium in culture media and transform inorganic selenium into its organic form via a bioconversion process (Figure 1).

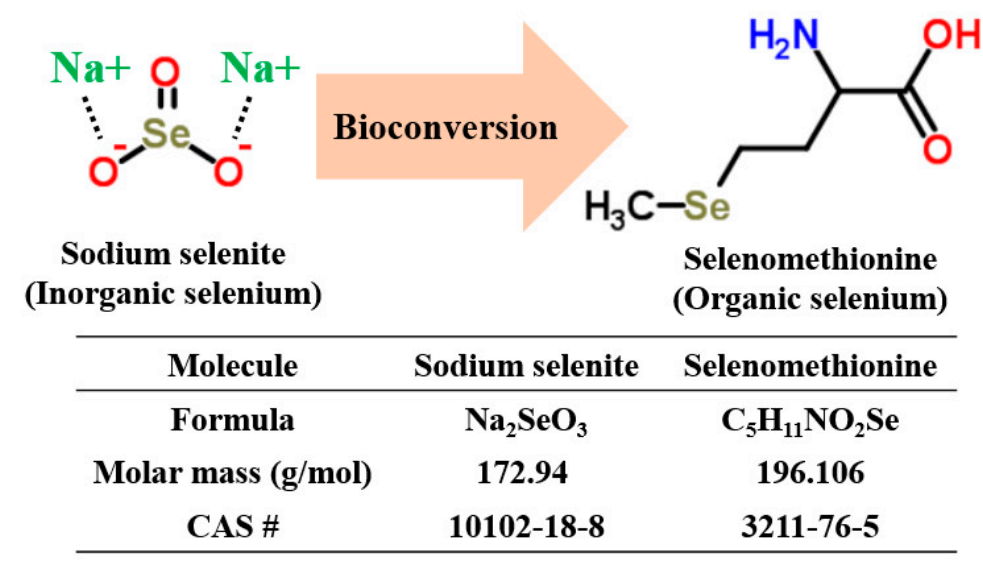

Figure 1. Bioconversion of inorganic selenium (sodium selenite) using microorganisms responsible for organic selenium (selenomethionine) production.

Using these selected microorganisms, certain organic selenium-enriched foods and feeds (e.g., selenium-enriched yeast cell biomass, wine and shiitake mushrooms) were developed. Therefore, multiple groups and scholars applied inorganic selenium into probiotics culture media as a media ingredient to produce organic selenium-enriched probiotics or fermented food; however, these studies have shown the limitations of prepared organic selenium-enriched probiotic bacteria due to low organic selenium yields and lethal effects of inorganic selenium on bacterial cell growth [20-22]. Accordingly, the harvested cell mass and organic selenium concentrations in the selenium-enriched bacteria were not satisfactory. Hence, the effective production of probiotic bacteria and their functional biogenic 
metabolites in a reproducible manner is required to achieve high biomass, high organic selenium yields, and reduced operational costs. The objectives of this project are to: (i) identify the probiotic strains resistant to inorganic selenium present in the culture medium; (ii) evaluate the influence of high sodium selenite levels on selected microbial growth; (iii) counteract the reduced cell mass due to poor selenium tolerance by probiotic strains using a controlled culture condition; and (iv) evaluate the selenium uptake efficiencies and biocatalytic properties of promising strain(s) capable of providing dual health functions (as both a selenium supplement and intestinal bacteria regulator).

\section{Results and Discussions}

\subsection{Subsection Cell Screening and the Effect of the Cultivation Conditions on the Bacterial Cell Mass}

Whole-cell biocatalysts are widely used to efficiently biosynthesize value-added products by increasing the bioavailability with bioconversion of existing bioactive materials [23-26]. According to Mrvčić et al. [27], whole cells of certain lactic acid bacteria (LAB) species can assimilate metalloid ions in culture media and accumulate the metalloproteins intracellularly via two basal mechanisms: biosorption and bioaccumulation. Generally, the low level of sodium selenite has enhanced the microbial growth rates and amino acids levels of Lactobacillus spp.; however, a high level of selenium inhibited the bacterial growth and triggered biological detoxification by converting sodium selenite to elemental selenium, which had significantly accumulated in the microorganism periphery [21,22]. Thus, organic selenium is obtained either from the surface binding of elemental or inorganic selenium [28]. After the inorganic selenium is deposited within the microorganism, the molecule is converted into organic selenium by the microorganism. Thus, the yield of organic selenium may increase proportionally with the amount of cell biomass produced. For the preliminary screening process, nine LAB strains were cultured in $15 \mathrm{~mL}$ of modified de Man, Rogosa and Sharpe (MRS) media containing with a high level of sodium selenite $(1 \mathrm{mM}, 172.9 \mathrm{mg} / \mathrm{L})$ for $18 \mathrm{~h}$. When cultured in the modified MRS media containing sodium selenite (mMRS-SS), microorganisms express a blood or dark red color or maroon hue. The culture medium turned red during the incubation following the addition of sodium selenite. According to Xia et al. [22], the red color of the medium was the result of the formation of non-toxic elemental selenium after the experimental cells were treated with a high selenium concentration $(>4 \mathrm{mg} / \mathrm{L})$.

After cell cultivation, washing and freeze-drying processes were carried out to obtain pure and dried cell biomass. Among the nine strains of LAB, four strains of Lactobacillus (L. reuteri KCTC 53608, L. cremoris ATCC 19257, L. plantarum, and L. brevis GABA100) were inhibited by the presence of $1 \mathrm{mM}$ of sodium selenite in the media. The level of recovered cell biomass of L. reuteri KCTC 53608, L. cremoris ATCC 19257, L. plantarum, and L. brevis GABA100 were $3.5 \pm 0.3,3.7 \pm 0.3,1.1 \pm 0.3$, and $4.4 \pm 0.3 \mathrm{mg}$, respectively $(n=3)$. The four Lactobacillus strains with low biomass yields $(<5 \mathrm{mg}$ of recovered cell biomass) were excluded from subsequent experiments. The five LAB strains that showed resistance to sodium selenite (L. bulgaricus KCTC 3188, L. acidophilus KCTC 3142, L. casei KFRI 704, L. brevis 353, and B. bifidum BGN4) were used to evaluate cell growth under various selenium treatment conditions to quantify the total selenium content of cells and to evaluate the selenium species produced.

To reduce the toxicity of sodium selenite, the cultivation conditions were divided into two phases: (i) the microbial growth and proliferation phase, during which the probiotic microorganisms were proliferated to the required levels; and (ii) the organic selenium production and accumulation phase, during which the sodium selenite stock solution was fed to the cell culture. We used a two-step fed-batch technique in which the substrate is treated with the microbial medium over time to prevent the substrate from adversely affecting microbial growth. Specifically, two-step fed-batch cultivation methods are considered a cultivation option for simple systems in which the microbial media ingredients and/or substrates are toxic to the beginning of a batch process [29]. These culture methods have been utilized to achieve high levels of microbial production and/or 
animal cell replication as a result of high cell biomass recovery, over a relatively large span of time, under the toxic conditions [30].

L. bulgaricus KCTC 3188, L. acidophilus KCTC 3142, L. casei KFRI 704, L. brevis 353, and B. bifidum BGN4 were cultured under various culture conditions and the recovered cell biomasses under these conditions were compared to the biomass produced in common MRS. Table 1 shows the changed dry weights of the selenium-enriched LAB biomass $(n=3)$ as a function of sodium selenite addition into the cell growth medium.

Table 1. Dry weight of selenium-enriched microorganism grown in de Man, Rogosa and Sharpe (MRS) containing $1 \mathrm{mM}(172.9 \mathrm{mg} / \mathrm{L})$ of sodium selenite. Data is shown as the mean $\pm \mathrm{SD}$ of the triplicate experiments.

\begin{tabular}{cccc}
\hline \multirow{2}{*}{ Cell Strains } & \multicolumn{2}{c}{ Dry Weight of Selenium-Enriched LAB (mg) } \\
\cline { 2 - 4 } & SS ${ }^{\mathbf{1}}$ Added at $\mathbf{~} \mathbf{~ h}$ & SS Added at $\mathbf{1 2}$ h & Control (No SS Added) \\
\hline L. bulgaricus KCTC 3188 & $15 \pm 0.62^{* *}$ & $24.3 \pm 0.55$ & $25 \pm 0.38$ \\
L. acidophilus KCTC 3142 & $16.3 \pm 0.40^{* *}$ & $22.8 \pm 0.42$ & $22.3 \pm 0.26$ \\
L. casei KFRI 704 & $15 \pm 0.49^{* *}$ & $25.6 \pm 0.31$ & $25.8 \pm 0.56$ \\
L. brevis 353 & $21 \pm 0.49^{* *}$ & $31.1 \pm 0.55$ & $30.5 \pm 0.81$ \\
B. bifidum BGN4 & $5.3 \pm 0.50^{* *}$ & $20.9 \pm 0.53$ & $22 \pm 0.35$ \\
\hline
\end{tabular}

${ }^{1}$ SS denotes Sodium Selenite. ${ }^{* *}$ Values are significantly different compared to the control group $(p<0.01)$.

The addition of sodium selenite at $12 \mathrm{~h}$ did not lead to a statistically significant reduction of the cell mass $(n=3, p>0.01)$. On the other hand, the addition of sodium selenite at $0 \mathrm{~h}$ significantly inhibited the growth of L. bulgaricus KCTC 3188, L. acidophilus KCTC 3142, L. casei KFRI 704, L. brevis 353, and B. bifidum BGN4 by 40, 26.9, 41.9, 31.1, and 75.9\%, respectively, compared to the control group ( $n=3, p<0.01)$. Selenium compounds inhibited the growth of Staphylococcus aureus, Lactobacillus, and Bifidobacterium. [21,31,32].

According to Diowksz et al. [33], cell growth inhibition of three LAB (L. casei, L. brevis, and L. sanfrancisco) was demonstrated with $\geq 1 \mathrm{mg} / \mathrm{L}$ of selenium dioxide. Andreoni et al. [34] reported that a concentration of sodium selenite exceeding $1 \mathrm{mg} / \mathrm{L}$ inhibited the growth of L. paracasei, L. kefir, and L. rhamnosus. Despite the fact that we added $172.9 \mathrm{mg} / \mathrm{L}$ of sodium selenite to the culture media in this study, levels of selenium-enriched LAB biomass were not notably decreased, as compared to the control group. Since the addition of selenium $12 \mathrm{~h}$ after incubation did not lead to a reduction of the final probiotic cell mass, the present preliminary method offers an effective solution for overcoming the reduction of bacterial cell mass caused by poor microbial selenium tolerance.

\subsection{Quantification and Qualification of Organic Selenium in Microorganisms}

Based on the previously mentioned data, sodium selenite was added to the MRS media after $12 \mathrm{~h}$ incubation and the total amount of organic selenium in the harvested cells was quantified. Endopeptidase hydrolysis was conducted to degrade the cell structure prior to the selenium species analysis. Endopeptidase has been used to break down the peptide bonds of selenium-containing proteins in selenium enriched microorganisms. This method is also considered the most effective pre-treatment of selenium species [35,36]. Table 2 shows total organic selenium content of selenium-enriched LAB quantified using inductively coupled plasma-atomic emission spectrometer (ICP-AES).

L. casei KFRI 704 showed the lowest organic selenium concentration $(35 \pm 0.2 \mu \mathrm{g} / \mathrm{g}, n=3)$ and B. bifidum BGN4 produced the highest concentration of total organic selenium $(207.51 \pm 25 \mu \mathrm{g} / \mathrm{g}, n=3)$. The total organic selenium production of B. bifidum BGN4 was significantly higher $(n=3, p<0.01)$ when sodium selenium was added to the culture after $12 \mathrm{~h}$, although the yield of B. bifidum BGN4 biomass was significantly low compared to the other four strains $(n=3, p<0.01)$. Multiple researchers and research groups have shown that when inorganic selenium (sodium selenite and selenium dioxide) is supplied to a cell culture media, selenium molecules accumulate in the cellular membrane and/or 
intracellular region of $\mathrm{LAB}$ in the form of selenoproteins or elemental selenium. In liquid media, dissolved sodium selenite is generally present as selenite $\left(\mathrm{Se}^{+4}\right)$ and /or selenate $\left(\mathrm{Se}^{+6}\right)$. According to Xia et al. [21] and Diowksz et al. [33] L. plantarum and L. bulgaricus deposit elemental selenium via cell detoxification. In Figure 2a, a typical HPLC-ICP-MS chromatogram of selenium standards is shown with the following elution times ( $\mathrm{sec})$ : methylselenocysteine, tret $=170-180$; selenite, tret $=230-240$; selenomethionine, tret $=300-310$; and selenate, tret $=670-680$. The ICP-MS chromatogram in Figure $2 \mathrm{~b}$ shows the chromatographic profiles of enzymatically-extracted organic selenium from selenium-enriched B. bifidum BGN4 analyzed via HPLC-ICP-MS. As shown in Figure 2b, the major species of selenium-enriched B. bifidum BGN4 was selenomethionine $(169.6 \mu \mathrm{g} / \mathrm{g})$.

Table 2. Total Organic Selenium in Selenium-Enriched Microorganisms Quantified using inductively coupled plasma-atomic emission spectrometer (ICP-AES). Data is shown as the mean $\pm \mathrm{SD}$ of the triplicate experiments.

\begin{tabular}{cc}
\hline Cell Strains & Total Organic Selenium Content of LAB $(\mu \mathrm{g} / \mathbf{g})$ \\
\hline L. bulgaricus KCTC 3188 & $111.7 \pm 0.16^{\mathrm{a}}$ \\
L. acidophilus KCTC 3142 & $134.4 \pm 1.18^{\mathrm{b}}$ \\
L. casei KFRI 704 & $35 \pm 0.20^{\mathrm{c}}$ \\
L. brevis 353 & $111.8 \pm 0.86^{\mathrm{a}}$ \\
B. bifidum BGN4 & $207.5 \pm 1.25^{\mathrm{d}}$ \\
\hline
\end{tabular}

$\mathrm{a}, \mathrm{b}, \mathrm{c}, \mathrm{d}$ Values of different superscripts within the same columns indicate significant differences.

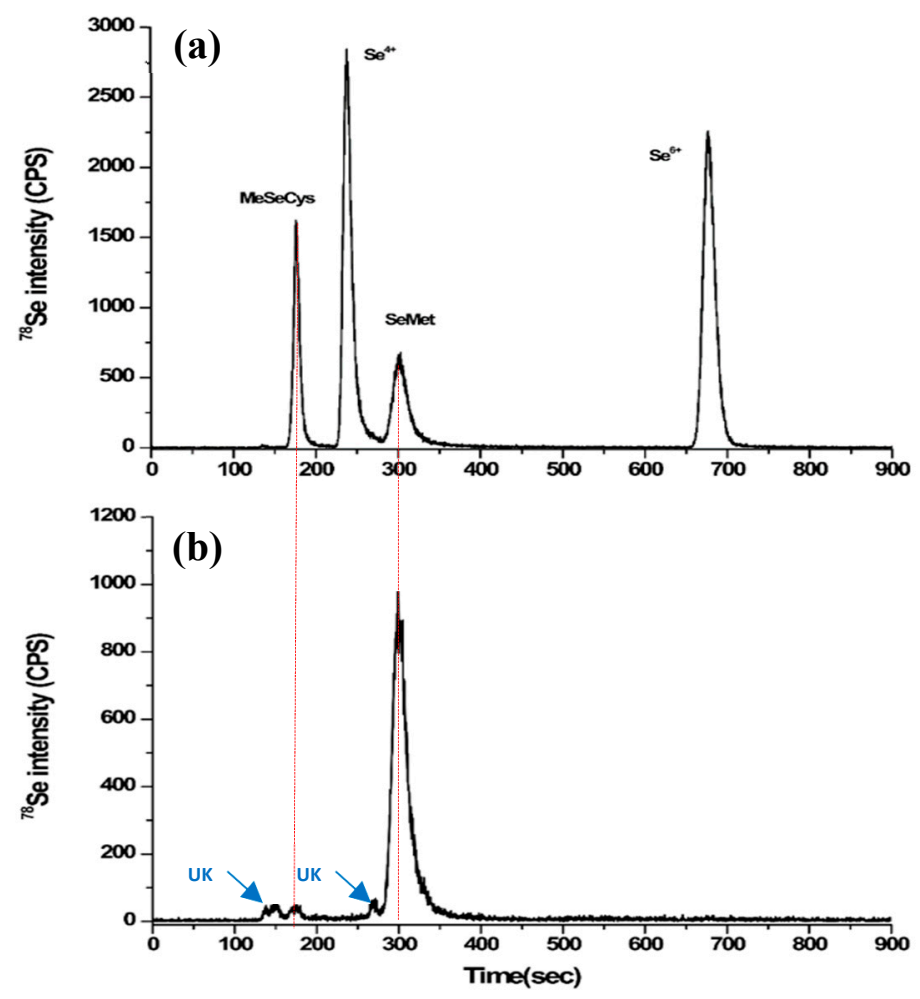

Figure 2. The cromatographic profiles of a standard selenium mixture (a) and enzymatically-extracted organic selenium from selenium-enriched B. bifidum BGN4 (b) analyzed by HPLC-ICP-MS. UK denotes unknown.

Low levels of methylselenocysteine and two other unknown substances were identified. However, neither selenite $\left(\mathrm{Se}^{4+}\right)$ nor selenate $\left(\mathrm{Se}^{6+}\right)$ were detected in the sample. According to Yin et al., [37], B. longum NQ-1501 cultured in trypticase-phytone-yeast extract (TPY) media containing sodium selenite produced a total of $82 \mu \mathrm{g} / \mathrm{g}$ organic selenium. In their work, $<60 \mu \mathrm{g} / \mathrm{g}$ (about $60 \%$ ) of 
organic selenium was selenomethionine. Multiple research groups have developed selenium-enriched fermented food products. Alzate [38] reported methylselenocysteine- and selenocysteine-enriched yogurt containing $0.7 \mu \mathrm{g} / \mathrm{g}$ of total selenium. Penas et al. [39] and Bryszewska et al. [40,41] also reported selenomethylcysteine- $(1.29 \mu \mathrm{g} / \mathrm{g})$ and selenomethionine- enriched $(3.56 \mu \mathrm{g} / \mathrm{g})$ sauerkraut and bread, respectively.

A previous study suggested that the relative bioavailability of selenomethionine compared to sodium selenite is $147 \%$ for liver glutathione peroxidase activity and $336 \%$ for weight gain in channel catfish, which indicates that the selenium requirement in the diets of channel catfish is reduced by selenomethionine more so than by inorganic selenium [42]. Claire et al. [43] suggested that selenomethionine inhibited the growth of human tumor cell lines (MCF-7/S breast carcinoma, DU-145 prostate cancer cells, and UACC-375 melanoma) over the range of 45-130 $\mu \mathrm{M}$. The growth inhibition of normal diploid fibroblasts required $1 \mathrm{mM}$ selenomethionine, much higher than the requirements of cancer cell lines. The bioavailability and low toxicity of selenomethionine make it an appropriate supplemental form of selenium for humans and animals [44]. According to the Toxnet of the National Institutes of Health (NIH), selenomethionine is about 40 times less toxic than sodium selenite as measured by laboratory animal toxicity. [45]. Specifically, the median lethal dose (LD50) of selenium forms are as follows: $7 \mathrm{mg} / \mathrm{kg}$ for sodium selenite [46] and $25.6 \mathrm{mg} / \mathrm{kg}$ for selenomethionine [47]. The minimum selenium requirement for the prevention of Keshan disease is $20 \mu \mathrm{g} /$ day. The physiological requirement for maximal glutathione peroxidase (GPx) and selenoprotein $P$ is estimated to be $45-50 \mu \mathrm{g} /$ day and $30 \mu \mathrm{g} /$ day for iodothyronine 5 deiodinases (IDIs). In addition, protection against some cancers, such as lung and prostate, requires $120 \mu \mathrm{g} /$ day [48].

Considering that the US RDA of selenium is $55 \mu \mathrm{g} /$ day [7] and the amount of selenomethionine produced by B. bifidum BGN4 is $169.6 \mu \mathrm{g} / \mathrm{g}$, B. bifidum BGN4 could be used under the growth conditions described herein to produce sufficient selenomethionine levels for commercial biofunctional applications. B. bifidum BGN4 is considered one of the most promising probiotics, given its clinically proven benefits and widespread commercial use [13]. Research has suggested that the oral feeding of B. bifidum BGN4 can prevent T cell-mediated inflammatory bowel disease and eczema in infants via immunomodulatory effects $[49,50]$. Multiple in vivo and in vitro experiments using B. bifidum BGN4 showed its strong cell adhesion properties, anti-carcinogenic effects on cell lines, cell safety and suppressed allergic responses in mouse models [13,15,51]. Given the low toxicity of elemental selenium, the high bioactivity of selenomethionine, and the high selenium uptake efficiency of B. bifidum BGN4 shown in the current study, selenium-enriched B. bifidum BGN4 may be an excellent vehicle for supplementation of dietary selenium and regulation of intestinal bacteria.

\section{Materials and Methods}

\subsection{Microbial Culture Condition and Initial Cell Screening}

Three replicate pre-cultures of nine LAB (Lactobacillus reuteri KCTC 53608, Lactobacillus bulgaricus KCTC 3188, Lactobacillus acidophilus KCTC 3142, Lactobacillus casei KFRI 704, Lactobacillus cremoris ATCC 19257, Lactobacillus plantarum, Lactobacillus brevis 353, Lactobacillus brevis GABA100, and Bifidobacterium bifidum BGN4) were created by inoculating at $1 \%(v / v)$ from a glycerol frozen stock $\left(-80{ }^{\circ} \mathrm{C}\right)$ in MRS media and stored for $18 \mathrm{~h}$ under anaerobic conditions at $37{ }^{\circ} \mathrm{C}$ prior to use. All cell strains were obtained from BIFIDO Co., Ltd. (Hongchen, Korea). The activated microorganisms were inoculated in a commercially-available MRS medium (DifcoTM \& BBLTM, IL, USA) and modified MRS media containing sodium selenite, mMRS-SS. A sodium selenite $\left(\mathrm{Na}_{2} \mathrm{O}_{3} \mathrm{Se}\right.$, Sigma-Aldrich, St. Louis, MO, USA) stock solution (172.9 mg dissolved in $10 \mathrm{~mL}$ of DW) was prepared and filtered using a $0.2 \mu \mathrm{m}$ syringe filter. Fifteen $\mu \mathrm{L}$ of this stock solution was added to the MRS culture medium $(15 \mathrm{~mL})$ to produce mMRS-SS. The final sodium selenite concentration in the culture medium was adjusted to $1 \mathrm{mM}$. The initial $\mathrm{pH}$ of the culture broths was adjusted to 7.0 via $1 \mathrm{~N} \mathrm{NaOH}$ at $25{ }^{\circ} \mathrm{C}$. All culture media were supplemented with $0.05 \%(w / v)$ L-cysteine hydrochloride to maintain 
anaerobic microbial culture conditions. Naturally-occurring microbiota from the MRS and mMRS-SS media were removed using a $0.2 \mu \mathrm{m}$-cutoff syringe microfilter membrane (Stericup ${ }^{\circledR}$-GV Filter Units, Burlington, MA, USA). Each medium was inoculated with $1 \%(v / v)$ activated-inoculum culture and then anaerobically cultured at $37^{\circ} \mathrm{C}$ for $18 \mathrm{~h}$ in a water bath $(150 \mathrm{rpm})$. Of the nine LAB strains, five cell strains (L. bulgaricus KCTC 3188, L. acidophilus KCTC 3142, L. casei KFRI 704, L. brevis 353, and B. bifidum BGN4) showed resistance to sodium selenite via the initial cell screening process. The cell biomasses were harvested by centrifugation $(139 \times g, 20 \mathrm{~min})$ and washed twice with deionized water (DI) before being freeze-dried. The biomass from each culture was weighed after freeze-drying.

\subsection{Selection of Selenium-Enriched Probiotics}

The ultimate goal of this study was to stimulate microorganisms to produce organic selenium from inorganic selenium, so it was imperative to measure the toxicity of inorganic selenium to probiotic cells. Fed batch processing is a commonly used culture technique to reduce the toxicity of certain media components and produce large quantities of secondary metabolites from microorganisms. Two-step fed-batch fermentations were conducted for the effective production of cell biomass in this study. The first cultivation step was to increase the total probiotic cell biomass via conventional MRS feeding $[29,30]$. The second step was designed to minimize the toxicity of sodium selenite and increase organic selenium productivity by supplementing sodium selenite to the MRS media. The five selected strains of cells were cultivated in MRS media for $12 \mathrm{~h}$, after which $1 \mathrm{mM}$ of sodium selenite was added as an inorganic selenium substrate to the media. All cell samples were cultured in a shaking water bath $\left(37^{\circ} \mathrm{C}, 150 \mathrm{rpm}\right)$ for an additional $36 \mathrm{~h}$ (a total of 2 days). The selenium-enriched microbial samples were harvested by centrifugation $(139 \times g, 20 \mathrm{~min})$, washed twice with DI, and freeze dried. Biomass weights were measured as previously described.

\subsection{Quantification of Total Selenium, Organic Selenium, and Selenium Species}

Enzymatic hydrolysis using endopeptidase has been proven to be the most effective method for the quantification of organic selenium species without altering their oxidation states [52]. Therefore, proteolytic treatments were conducted in this study for the quantification of total selenium and total organic selenium. For the extraction of the total organic selenium compounds and assessment of the selenium species, the selenium-enriched LAB powder harvested from $15 \mathrm{~mL}$ of culture was dissolved in $5 \mathrm{~mL}$ of phosphate buffer containing $20 \mathrm{mg}$ of pronase $\mathrm{E}$ from Streptomyces griseus (metalloendopeptidases, 4,000,000 PU/g, EC 3.4.24.4) and incubated at $37^{\circ} \mathrm{C}$ for $16 \mathrm{~h}[35,36]$. The samples were then filtered through a sterile filter $(0.45 \mu \mathrm{m}$, Pall Corporation, Port Washington, NY, USA). Total organic selenium was quantified using an inductively coupled plasma-atomic emission spectrometer (ICP-AES, Optima-4300 DV, Perkin Elmer, Norwalk, CT, USA). Selenium species determination was performed using an inductively coupled plasma mass spectrometer (ICP-MS, Agilent 7700, Agilent Technologies, Tokyo, Japan) equipped with an octopole collision cell. Chromatographic separations were performed using a Model 1260 HPLC pump (Agilent, Wilmington, DE, USA) as the delivery system. The selenium species were separated using a Hamilton (Reno, NV, USA) PRP X-100 anion exchange column $(250 \mathrm{~mm} \times 4.1 \mathrm{~mm}$ id, $10 \mu \mathrm{m}$ particles $)$ at $40{ }^{\circ} \mathrm{C}$. The flow rate was maintained at $1 \mathrm{~mL} / \mathrm{min}$, and the injection volume was $20 \mu \mathrm{L}$. The mobile phase consisted of $2 \mathrm{mM}$ ammonium citrate in $2 \%$ methanol (Solution A) and $10 \mathrm{mM}$ ammonium citrate in $2 \%$ methanol (Solution B). The gradient elution began with $80 \%$ solution $\mathrm{A}$ and $20 \%$ solution $\mathrm{B}$ and was adjusted as follows: A from $80 \%$ to $0 \%, 2-10 \mathrm{~min}$; and A from $90 \%$ to $82 \%, 10-18 \mathrm{~min}$. The ICP-MS operating conditions were as follows: forward power of $1550 \mathrm{~W}$; plasma gas flow rate of $10.5 \mathrm{~L} / \mathrm{mL}$; carrier gas flow rate of $0.8 \mathrm{~L} / \mathrm{mL}$; makeup gas flow rate of $0.30 \mathrm{~L} / \mathrm{min}$; sample depth of $8.0 \mathrm{~mm}$; collision gas (He gas) flow of $3.5 \mathrm{~mL} / \mathrm{min}$; quadrupole bias of $-16 \mathrm{~V}$; octopole bias of $-18 \mathrm{~V}$; and isotopes monitoring at 77Se and 78Se. Seleno-DL-methionine (C5H11NO2Se) and se-(methyl) selenocysteine hydrochloride $(\mathrm{C} 4 \mathrm{H} 9 \mathrm{NO} 2 \mathrm{Se} \cdot \mathrm{HCl})$ were used as the HPLC-ICP-MS standards. Enzyme pronase E (protease XIV type) was purchased from Sigma-Aldrich (St. Louis, MO, USA). A phosphate buffered 
saline (PBS) was prepared by dissolving $8 \mathrm{~g} \mathrm{NaCl}, 0.2 \mathrm{~g} \mathrm{KCl}$, $1.44 \mathrm{~g} \mathrm{Na}_{2} \mathrm{HPO}_{4}$, and $7.4 \mathrm{~g} \mathrm{KH}_{2} \mathrm{PO}_{4}$ in $1 \mathrm{~L}$ of DI with a final $\mathrm{pH}$ of 7.4 . The buffer was autoclaved at $121^{\circ} \mathrm{C}$ for $15 \mathrm{~min}$ prior to use.

\subsection{Statistical Analysis}

Experiments were performed in triplicate, and the data were shown as mean \pm standard deviation. A t-test and one-way analysis of variance (ANOVA) with Duncan post-hoc test $(p<0.01)$ were performed with the statistics package GNU R, version 3.1.2 [30].

\section{Conclusions}

Selenium is a trace element that is essential to human health and has received considerable attention due to its nutritional value. Various microorganism strains were screened to select the strains with inorganic selenium uptake properties and the ability to transform inorganic selenium to the organic form. However, due to the microorganisms' poor inorganic selenium tolerance, the growth of selenium-enriched cells was inhibited by a small quantity of sodium selenite. To solve the poor selenium tolerance of lactic acid bacteria and identify a strain with both high selenium uptake efficiency and the ability to transform inorganic selenium into an organic form, this experiment utilized nine strains of edible lactic acid bacteria. The total amount of selenium was quantified using an inductively coupled plasma-atomic emission spectrometer (ICP-AES). The selenium species were separated via anion-exchange chromatography and analyzed using inductively coupled plasma-mass spectrometry (ICP-MS). The reduction of bacterial cell mass due to inorganic selenium toxicity was solved by an adjustment of the time of selenium addition (12 h after incubation), and B. bifidum BGN4 was found to be the most potent selenium-enriched strain. The adjusted selenium addition time enhanced the cell mass of the selenium-enriched B. bifidum BGN4 by overcoming the microorganisms' poor selenium tolerance. Chromatography results showed that selenomethionine $(169.6 \mu \mathrm{g} / \mathrm{g})$ was the main organic selenium form in selenium-enriched B. bifidum BGN4. Considering that B. bifidum BGN4 is a well-known probiotic strain with clinically-proven benefits, selenium-enriched B. bifidum BGN4 may provide dual healthy functions, both as a daily selenium supplement and an intestinal bacteria regulator.

Author Contributions: W.J. initiated and finished this work under the supervision of S.K. and G.E.J. W.J. and C.Y. performed the sample preparation, microbial screening and HPLC analysis. W.J., S.K. and G.E.J. collaboratively analyzed data, wrote the manuscript and performed the literature review. S.K. and T.V.J. edited and revised the manuscript based on a non-disclosure research agreement between Middle Tennessee State University and BIFIDO Co., Ltd. All authors discussed the drafts and approved the final manuscript for publication.

Funding: This work was carried out with support from the " National Research Foundation of Korea 450 (NRF) grant (No. 2017R1A2B2012390) funded by the Korea government (MSIP), High Value-added Food Technology Development Program (No. 317043-3), Korea Institute of Planning and Evaluation for Technology in Food, Agriculture, Forestry and Fisheries (IPET), Ministry of Agriculture, Food and Rural Affairs (MAFRA), and the Faculty Research and Creative Activity Committee (FRCAC) grant (No. 221745) funded by Middle Tennessee State University (MTSU).

Acknowledgments: In this section you can acknowledge any support given which is not covered by the author contribution or funding sections. This may include administrative and technical support, or donations in kind (e.g., materials used for experiments).

Conflicts of Interest: The authors declare no conflicts of interest.

\section{References}

1. Stranges, S.; Marshall, J.R.; Trevisan, M.; Natarajan, R.; Donahue, R.; Combs, G.F.; Farinaro, E.; Clark, L.C.; Reid, M.E. Effects of Selenium Supplementation on Cardiovascular Disease Incidence and Mortality: Secondary Analyses in A Randomized Clinical Trial. Am. J. Epidemiol. 2006, 163, 694-699. [CrossRef] [PubMed]

2. Finley, J.; Ip, C.; Lisk, D.; Davis, C.; Hintze, K.; Whanger, P. Cancer-Protective Properties of High-Selenium Broccoli. J. Agric. Food Chem. 2001, 49, 2679-2683. [CrossRef] [PubMed] 
3. Rayman, M. The Importance of Selenium to Human Health. Lancet 2000, 356, 233-241. [CrossRef]

4. Chen, X. Selenium and Cardiomyopathy (Keshan Disease). Acta Pharmacol. Toxicol. 2009, 59, 325-330. [CrossRef]

5. Moreno-Reyes, R.; Suetens, C.; Mathieu, F.; Begaux, F.; Zhu, D.; Rivera, M.; Boelaert, M.; Nève, J.; Perlmutter, N.; Vanderpas, J. Kashin-Beck Osteoarthropathy In Rural Tibet In Relation to Selenium and Iodine Status. N. Engl. J. Med. 1998, 339, 1112-1120. [CrossRef] [PubMed]

6. Wei, J.; Zeng, C.; Gong, Q.; Yang, H.; Li, X.; Lei, G.; Yang, T. The Association Between Dietary Selenium Intake and Diabetes: A Cross-Sectional Study Among Middle-Aged and Older Adults. Nutr. J. 2015, 14, 18. [CrossRef] [PubMed]

7. Monsen, E.R. Dietary Reference Intakes for Vitamin C, Vitamin E, Selenium, and Carotenoids. J. Am. Diet. Assoc. 2000, 100, 637-640. [CrossRef]

8. Aquilina, G.; Azimonti, G.; Bampidis, V.; de Lourdes Bastos, M.; Bories, G.; Chesson, A.; Cocconcelli, P.S.; Flachowsky, G.; Gropp, J.; Kolar, B.; et al. Safety and Efficacy of Selenium Compounds (E8) As Feed Additives for All Animal Species: Sodium Selenite, Based on A Dossier Submitted by Retorte Gmbh Selenium Chemicals and Metals. EFSA J. 2016, 14, 4398.

9. Brown, K.; Pickard, K.; Nicol, F.; Beckett, G.; Duthie, G.; Arthur, J. Effects of Organic and Inorganic Selenium Supplementation on Selenoenzyme Activity in Blood Lymphoctyes, Granulocytes, Platelets and Erythrocytes. Clin. Sci. 2000, 98, 593-599. [CrossRef] [PubMed]

10. Mahima, A.; Kumar, A.; Amit, K.; Anu, R.; Vinod, K.; Debashis, R. Inorganic Versus Organic Selenium Supplementation: A Review. Pak. J. Biol. Sci. 2012, 15, 418-425. [PubMed]

11. Probiotics Market Size, Share \& Trends Analysis Report by Application (Food \& Beverages, Dietary Supplements, Animal Feed), By End-Use, By Region, And Segment Forecast, 2018-2024. Available online: \unhbox\voidb@x\hbox\{http://www.grandviewresearch.com/industry-analysis/pr obiotics-market\} (accessed on 14 September 2018).

12. Global Probiotics Market 2017-2021. Available online: https://www.researchandmarkets.com/reports/423 1709/global-probiotics-market-2017-2021?gclid=Cj0KCQjw6NjNBRDKARIsAFn3NMrYxxMExFwUMz0F GGYeE31PNIu8sAgcXKxML_4qJqcNm94I9a4Gae4aApILEALw_wcB (accessed on 14 September 2018).

13. Ku, S.; Park, M.S.; Ji, G.E.; You, H.J. Review on Bifidobacterium bifidum BGN4: Functionality and Nutraceutical Applications as a Probiotic Microorganism. Int. J. Mol. Sci. 2016, 17, 1544. [CrossRef] [PubMed]

14. Park, M.S.; Kwon, B.; Ku, S.; Ji, G.E. The Efficacy of Bifidobacterium longum BORI and Lactobacillus acidophilus AD031 Probiotic Treatment in Infants with Rotavirus Infection. Nutrients 2017, 9, 887. [CrossRef] [PubMed]

15. Ku, S.; You, H.J.; Ji, G.E. Enhancement of Anti-Tumorigenic Polysaccharide Production, Adhesion, and Branch Formation of Bifidobacterium bifidum BGN4 by Phytic Acid. Food Sci. Biotechnol. 2009, 18, 749-754.

16. Pavli, F.; Tassou, C.; Nychas, G.; Chorianopoulos, N. Probiotic Incorporation in Edible Films and Coatings: Bioactive Solution for Functional Foods. Int. J. Mol. Sci. 2018, 19, 150. [CrossRef] [PubMed]

17. Hariharan, H.; Al-Dhabi, N.A.; Karuppiah, P.; Rajaram, S. Microbial synthesis of selinium nanocomposite using Saccharomyces cerevisiae and its antimicrobial activity against pathogens causing nosocomial infection. Chalcogenide Lett. 2012, 9, 509-515.

18. Zhang, L.; Li, D.; Gao, P. Expulsion of Selenium/Protein Nanoparticles Through Vesicle-Like Structures by Saccharomyces Cerevisiae Under Microaerophilic Environment. World J. Microbiol. Biotechnol. 2012, 28, 3381-3386. [CrossRef] [PubMed]

19. Nunes, R.; Luz, J.; Freitas, R.; Higuchi, A.; Kasuya, M.; Vanetti, M. Selenium Bioaccumulation in Shiitake Mushrooms: A Nutritional Alternative Source of This Element. J. Food Sci. 2012, 77, C983-C986. [CrossRef] [PubMed]

20. Deng, Y.; Man, C.; Fan, Y.; Wang, Z.; Li, L.; Ren, H.; Cheng, W.; Jiang, Y. Preparation of Elemental Selenium-Enriched Fermented Milk by Newly Isolated Lactobacillus Brevis from Kefir Grains. Int. Dairy J. 2015, 44, 31-36. [CrossRef]

21. Xia, S.; Chen, L.; Liang, J. Enriched Selenium and Its Effects on Growth and Biochemical Composition In lactobacillus Bulgaricus. J. Agric. Food Chem. 2007, 55, 2413-2417. [CrossRef] [PubMed] 
22. Zhang, B.; Zhou, K.; Zhang, J.; Chen, Q.; Liu, G.; Shang, N.; Qin, W.; Li, P.; Lin, F. Accumulation and Species Distribution of Selenium in Se-Enriched Bacterial Cells of The Bifidobacterium Animalis 01. Food Chem. 2009, 115, 727-734. [CrossRef]

23. Ku, S.; You, H.J.; Park, M.S.; Ji, G.E. Whole-cell biocatalysis for producing ginsenoside Rd from Rb1 using Lactobacillus rhamnosus GG. J. Microbiol. Biotechnol. 2016, 26, 1206-1215. [CrossRef] [PubMed]

24. Ku, S.; Zheng, H.; Park, M.S.; Ji, G.E. Optimization of $\beta$-glucuronidase activity from Lactobacillus delbrueckii $\mathrm{Rh} 2$ and and its use for biotransformation of baicalin and wogonoside. J. Korean Soc. Appl. Biol. Chem. 2011, 54, 275-280. [CrossRef]

25. Li, Y.; Ku, S.; Park, M.S.; Li, Z.; Ji, G.E. Acceleration of Aglycone Isoflavone and -Aminobutyric Acid Production from Doenjang Using Whole-Cell Biocatalysis Accompanied by Protease Treatment. J. Microbiol. Biotechnol. 2017, 27, 1952-1960. [CrossRef] [PubMed]

26. Ku, S.; You, H.J.; Park, M.S.; Ji, G.E. Effects of ascorbic acid on $\alpha$-L-arabinofuranosidase and $\alpha$-L-arabinopyranosidase activities from Bifidobacterium longum RD47 and its application to whole cell bioconversion of ginsenoside. J. Korean Soc. Appl. Biol. Chem. 2015, 58, 857-865. [CrossRef] [PubMed]

27. Mrvčić, J.; Stanzer, D.; Šolić, E.; Stehlik-Tomas, V. Interaction of Lactic Acid Bacteria with Metal Ions: Opportunities for Improving Food Safety and Quality. World J. Microbiol. Biotechnol. 2012, 28, 2771-2782. [CrossRef] [PubMed]

28. Mazo, V.; Gmoshinski, I.; Zorin, S. New Food Sources of Essential Trace Elements Produced by Biotechnology Facilities. Biotechnol. J. 2007, 2, 1297-1305. [CrossRef] [PubMed]

29. Ito, T.; Kikuta, H.; Nagamori, E.; Honda, H.; Ogino, H.; Ishikawa, H.; Kobayashi, T. Lipase Production in Two-Step Fed-Batch Culture of Organic Solvent-Tolerant Pseudomonas Aeruginosa LST-03. J. Biosci. Bioeng. 2001, 91, 245-250. [CrossRef]

30. Wang, T.; Tian, X.; Liu, T.; Wang, Z.; Guan, W.; Guo, M.; Chu, J.; Zhuang, Y. A Two-Stage Fed-Batch Heterotrophic Culture of Chlorella Protothecoides That Combined Nitrogen Depletion with Hyperosmotic Stress Strategy Enhanced Lipid Yield and Productivity. Process Biochem. 2017, 60, 74-83. [CrossRef]

31. Li, X.; Liu, Y.; Wu, J.; Liang, H.; Qu, S. Microcalorimetric Study of Staphylococcus Aureus Growth Affected by Selenium Compounds. Thermochim. Acta 2002, 387, 57-61.

32. Tran, P.A.; Webster, T.J. Selenium Nanoparticles Inhibit Staphylococcus Aureus Growth. Int. J. Nanomed. 2011, 6, 1553-1558.

33. Diowksz, A.; Ambroziak, W.; Wladarezyk, M. Investigation of ability of selenium accumulation by lactic acid bacteria of Lactobacillus sp. and yeast S. cerevisiae. Pol. J. Food Nutr. Sci. 1999, 49, 17-21.

34. Andreoni, V.; Luischi, M.M.; Cavalca, L.; Erba, D.; Ciappellano, S. Selenite tolerance and accumulation in the L. species. Ann. Microbiol. 2000, 50, 77-88.

35. Siwek, M.; Galunsky, B.; Niemeyer, B. Isolation of selenium organic species from antarctic krill after enzymatic hydrolysis. Anal. Bioanal. Chem. 2005, 381, 737-741. [CrossRef] [PubMed]

36. Reyes, L.H.; Guzman Mar, J.L.; Mizanur Rahman, G.M.; Seybert, B.; Fahrenholz, T.; Kingston, H.S. Simultaneous determination of arsenic and selenium species in fish tissues using microwave-assisted enzymatic extraction and ion chromatography-inductively coupled plasma mass spectrometry. Talanta 2009, 78, 983-990. [CrossRef] [PubMed]

37. Yin, Y.; Wang, R.R.; Wang, Y.; Wang, J.J.; Xu, G.X. Preparation of Selenium-enriched Bifidobacterium Longum and its Effect on Tumor Growth and Immune Function of Tumor-Bearing Mice. Asian Pac. J. Cancer Prev. 2014, 15, 3681-3686. [CrossRef] [PubMed]

38. Alzate, A.; Cañas, B.; Pérez-Munguía, S.; Hernández-Mendoza, H.; Pérez-Conde, C.; Gutiérrez, A.; Cámara, C. Evaluation of the Inorganic Selenium Biotransformation in Selenium-Enriched Yogurt by HPLC-ICP-MS. J. Agric. Food Chem. 2007, 55, 9776-9783. [CrossRef] [PubMed]

39. Penas, E.; Martinez-Villaluenga, C.; Frias, J.; Sanchez-Martinez, M.J.; Perez-Corona, M.T.; Madrid, Y.; Camara, C.; Vidal-Valverde, C. Se improves indole glucosinolate hydrolysis products content, Se-methylselenocysteine content, antioxidant capacity and potential anti-inflammatory properties of sauerkraut. Food Chem. 2012, 132, 907-914. [CrossRef]

40. Bryszewska, M.A.; Ambroziak, W.; Diowksz, A.; Baxter, M.J.; Langford, N.J.; Lewis, D.J. Changes in the chemical form of selenium observed during the manufacture of a selenium-enriched sourdough bread for use in a human nutrition study. Food. Addit. Contam. 2005, 22, 135-140. [CrossRef] [PubMed] 
41. Bryszewska, M.A.; Ambroziak, W.; Langford, N.J.; Baxter, M.J.; Colyer, A.; Lewis, D.J. The effect of consumption of selenium enriched rye/wheat sourdough bread on the body's selenium status. Plant Foods Hum. Nutr. 2007, 62, 121-126. [CrossRef] [PubMed]

42. Chinlu, W.; Richard, T.L. Organic selenium sources, selenomethionine and selenoyeast, have higher bioavailability than an inorganic selenium source, sodium selenite, in diets for channel catfish (Ictalurus punctatus). Aquaculture 1997, 152, 223-234.

43. Claire, R.; Julie, A.S.; Antonio, T.B.; Jenny, L.B.; Larry, C.C.; Cindy, C.; Denise, R.; Claire, M.P.; Mark, A.N. Inhibitory effect of selenomethionine on the growth of three selected human tumor cell lines. Cancer Lett. 1998, 125, 103-110.

44. Gerhard, N.S. Selenomethionine: A review of its nutritional significance, metabolism and toxicity. Am. Soc. Nutr. 2000, 130, 1653-1656.

45. Toxnet Toxicology Data Network. Available online: https://toxnet.nlm.nih.gov/cgi-bin/sis/search/a?dbs+ hsdb:@term+@DOCNO+3564 (accessed on 12 September 2018).

46. Cummins, L.; Kimura, E. Safety Evaluation of Selenium Sulfide Antidandruff Shampoos. Toxicol. Appl. Pharmacol. 1971, 20, 89-96. [CrossRef]

47. Zhang, J.S. Evaluation of nanotoxicity of foods and drugs: Biological properties of red elemental selenium at nano size (nano-Se) in vitro and in vivo. In Nanotoxicity: From In Vivo and In Vitro Models to Health Risks; Saura, C.S., Daniel, A.C., Eds.; John Wiley \& Sons, Inc.: Hoboken, NJ, USA, 2009; pp. 97-113.

48. Thomson, C. Assessment of requirements for selenium and adequacy of selenium status: A review. Eur. J. Clin. Nutr. 2004, 58, 391-402. [CrossRef] [PubMed]

49. Kim, H.; Lee, S.Y.; Ji, G.E. Timing of Bifidobacterium administration influences the development of allergy to ovalbumin in mice. Biotechnol. Lett. 2005, 27, 1361-1367. [CrossRef] [PubMed]

50. Kim, N.; Kunisawa, J.; Kweon, M.N.; Ji, G.E.; Kiyono, H. Oral feeding of Bifidobacterium bifidum (BGN4) prevents CD4+ CD45RB high T cell-mediated inflammatory bowel disease by inhibition of disordered $\mathrm{T}$ cell activation. Clin. Immunol. 2007, 123, 30-39. [CrossRef] [PubMed]

51. Kim, M.; Ku, S.; Kim, S.; Lee, H.; Jin, H.; Kang, S.; Li, R.; Johnston, T.; Park, M.; Ji, G. Safety Evaluations of Bifidobacterium bifidum BGN4 and Bifidobacterium longum BORI. Int. J. Mol. Sci. 2018, 19, 1422. [CrossRef] [PubMed]

52. Vonderheide, A.P.; Wrobel, K.; Kannamkumarath, S.S.; B'Hymer, C.; Montes-Bayón, M.; Ponce de León, C.; Caruso, J.A. Characterization of selenium species in Brazil nuts by HPLC-ICP-MS and ES-MS. J. Agric. Food Chem. 2002, 50, 5722-5728. [CrossRef] [PubMed]

Sample Availability: Selenomethionine-enriched Bifidobacterium bifidum BGN4 cells are available from the authors.

(C) 2018 by the authors. Licensee MDPI, Basel, Switzerland. This article is an open access article distributed under the terms and conditions of the Creative Commons Attribution (CC BY) license (http:/ / creativecommons.org/licenses/by/4.0/). 